\author{
ALICJA PALUCH \\ ORCID: 0000-0002-4310-2440 \\ Uniwersytet Opolski
}

\title{
Demographic determinants of the power of the state
}

\section{Introduction}

The influence of demographic determinants on the functioning and development of the state has been the subject of interest of different scientific disciplines for decades. International relations are one of the sub-disciplines that take this impact into special consideration. Within its framework, researchers try to answer whether and to what extent the size of population affects the power of the state concerned, and thus the balance of power in the world. Is the population a conditio sine qua non (essential condition) for recognising the state concerned as a great power? How do the condition and demographic structure impact the position of the state in the international arena, including its non-material, spiritual aspects (will, morale of the nation)? In this respect, it is vital to determine the existence of cause-and-effect relations between demographic potential and power, which has been the subject of deliberations by scientists on theoretical and empirical grounds.

The aim of this article is to identify a set of independent variables strongly correlated with the power of the state in the demographic area. Statistical methods for eliminating independent variables in the model of assessing demographic power of the state have been used in the research.

\section{Grounds for the conducted research}

The conviction of the fundamental importance of the population for society and the state can be attributed primarily to Jean Bodin, an outstanding thinker and 
theoretician of the state. His view of the wealth and strength of the nation being dependent on the population size is a statement having both opponents and supporters. For instance, John Mearsheimer, while examining the essence of the power of the state distinguished the population size and wealth as components of the potential power that underpin the building of military power. According to the scholar, only countries with large populations can generate great wealth, thus become great powers. ${ }^{1}$ This aspect has also been highlighted by Hans Morgenthau who stated that

although the claim that the state is powerful because it has a larger population is unfounded, it is true that no country can maintain or become a prime power unless it is one of the most populated countries in the world. ${ }^{2}$

The human factor was also pointed out by Halford Mackinder as he found that

the real balance of political powers at any given time is the result of geographical conditions, both economic and strategic one the one hand, and the relative population size, fortitude, equipment and organisation of competing people on the other. ${ }^{3}$

Hervé Le Bras, however, is in strong opposition to the position adopted by J. Bodin, claiming:

It is not true that people are the only wealth. The real wealth can be found in the social organisation, the structure of bonds that people as social animals can establish in order to live together. ${ }^{4}$

In this context, it is also worth recalling the opinion of Ludwik Wolski, professor of statistics and economist who argued that the population is the most important element of the country. When well arranged, it is its soul, power and glory. ${ }^{5}$ In the face of various views on this subject, it seems justified to assume, as Pierre Buhler, that

beneath a superficial foam of human actions, demography shapes in "long duration" $[\ldots]$ time and space of the world. Resistant to "engineering" undertakings, obedient to laws that the human mind has still not managed to penetrate, however, is in the very heart of this interpersonal relationship, namely the power. ${ }^{6}$

Demography is one of the most important platforms for shaping the international balance of power. This may be due to the extent to which this factor influences other

1 J. Mearsheimer, The Tragedy of Great Power Politics, New York 2001, p. 44.

2 H.J. Morgenthau, Polityka między narodami: walka o potęge i pokój, ed. K.W. Thompson, transl. R. Włoch, Warszawa 2010, p. 149. All citations in the Author's own translation.

3 H.J. Mackinder, "The geographical pivot of history", The Geographical Journal 23, 1904, no. 4 , p. 437.

${ }^{4}$ H. Le Bras, L'adieu aux masses. Demographie et politique, Paris 2002, p. 87.

5 After: K. Zając, "Z historii badań związków rozwoju społeczno-ekonomicznego a demograficznego", http://stat.gov.pl/cps/rde/xbcr/gus/POZ_Z_historii_badan_zwiazkow_rozwoju_spol-ekonom_a_ demogr.pdf (accessed: 25.08.2018).

${ }^{6}$ P. Buhler, O potędze w XXI wieku, transl. G. Majcher, Warszawa 2014, p. 224. 
partial attributes of the power of the state - economic, social, political and military ones. Changes in the demographic structure involve multifaceted consequences. The most important ones seem to be of economic nature. The labour force is essential in this respect. It is determined by the number of people in the working age (women 18-59; men 18-64), therefore its growth has a direct impact on production processes - shaping the level of gross domestic product. This subgroup is the basis not only for the number of employees, but also the number of soldiers, scientists, engineers and other leading professions. A significant number of people also stands behind a larger market (growing demand), whereas a declining population makes it necessary to raise taxes in order to maintain existing infrastructure and permanent government spendings. Another important process affecting the economic potential of the state is a decrease in fertility below the level of generational replacement with simultaneous extension of life expectancy, causing dynamic ageing of the society. It brings severe results in the form of limited economic growth in absolute terms as well as per capita, threatening public safety and decrease in social productivity. ${ }^{7}$ The ageing of the labour force in developed countries makes labour markets become "less flexible, less mobile and less innovative; rates of savings and investments are declining, deficits will appear or deepen in the current accounts, while foreign debt will increase". ${ }^{8}$ This phenomenon is also reflected in the scale of social needs. In this respect, the structure of social benefits and services is changing as there is a greater burden on the social security and health care systems. Consequently, this may lead to "budget tensions", causing a reduction in defence and foreign policy expenditures. In conditions of a shrinking economy, it is difficult to maintain military potential based on dynamically functioning arms industry and new technologies. However, also in this respect it is necessary to have an appropriate level of human resources. As noted by Waldemar Florczak and Michał Przybyliński

progressive mechanisation and automation of military equipment, and even the presence of nuclear weapon, do not make it unnecessary to care for the adequate development of conventional sources. ${ }^{9}$

Population size is also important in the political sphere. States' membership in certain international organisations is often conditioned by their direct economic potential (G8 and G20 Groups), which is largely determined by their population. It is also the basis for granting representations to individual Member States in certain bodies of the European Union (e.g. the European Commission, the European Parliament, with some weighted preferences in favour of small countries). ${ }^{10}$

7 W. Florczak, M. Przybyliński, "Zmiany w liczebności i strukturze populacji a rozwój społeczno-ekonomiczny”, Studia Ekonomiczne 2016, no. 3, p. 401.

8 J. Białek, A. Oleksiuk, Gospodarka i geopolityka. Dokad zmierza świat?, Warszawa 2009, p. 226.

9 W. Florczak, M. Przybyliński, op. cit., p. 401.

10 Ibid., pp. 401-402. 
A considerable size of the population in a given country may also cause many other consequences, such as difficulties with feeding the population, saturation of the labour market and thus an increase in economic migration, higher social expenditures of the state, increased pollution of the environment and consumption of natural resources. At this point, however, it should be highlighted that both presented sides (positive and negative) are mainly shaped by political conditions (political system, government quality, management system, etc.) and geographical conditions (location, topography of the area, climate, natural resources). The first one seems to be of fundamental importance, as Krzysztof Załęski claims "the crucial problem in shaping the state's great power comes down mainly to the concept of proper organisation of society and the use of its human strength". ${ }^{11}$ Furthermore, the demographic factor has a positive impact on the power of the state only if it coexists harmoniously with a high level of economic and social development. It is also crucial not to identify human capital solely with the population size as its quality is equally important, that is the level of education, mobility, state of health, distribution of average age, spirit and moral values, ability to take collective actions. For that reason, population growth itself does not increase the power of the state. ${ }^{12}$ According to the author of the article, this takes place only as a result of cooperation and mutual stimulation with other dimensions of the power of a political entity (both material and non-material possibilities).

\section{Demographic factors in determining the power of the state}

One of the most important entities controlling the global international system is great power. The diversity and multiplicity of definitions of this subject of international relations allow only for a selective presentation of its meanings. According to Teresa Łoś-Nowak, a great power is a state that occupies a central position in the system of international relations which "with its power, and therefore the power of influence is rather clearly superior when compared to other countries". ${ }^{13}$ Dariusz Kondrakiewicz identifies a great power with a state possessing strength or power, which manifests itself in "the ability to effectively impact the behaviour of other international participants, and in the event of their resistance allowing the use of all available means, including force". ${ }^{14}$

${ }^{11}$ K. Załęski, Międzynarodowe stosunki polityczne. Wybrane problemy, Dęblin 2011, p. 105.

12 M. Łakomy, "Bezpieczeństwo demograficzne a potęga państw", Przegląd Geopolityczny 19, 2017, p. 135-136.

13 T. Łoś-Nowak, ed., Stosunki międzynarodowe, Kraków 2002, p. 221.

14 D. Kondrakiewicz, "Państwo", [in:] Międzynarodowe stosunki polityczne, ed. M. Pietraś, Lublin 2006, p. 83. 
In the above and in many other definitions, one can notice the presence of one element, namely p ow er. This category, similarly to a great power takes on a multidimensional definition range. For example, John Stoessinger claims that "power in international relations is the ability of the state to use its material and non-material resources in a way that will affect the behaviour of other states". 15 Robert Dahl presents it as "the ability to get others to do something they would not otherwise do". ${ }^{16}$ According to Raymond Aron, it is "the ability to do, create or destroy". ${ }^{17}$

A review of existing approaches to determining the power of the state allows us to form a statement according to which the traditional and commonly recognised criteria that make up the power of the state include territory, population potential, economic and scientific-technical potential, moral and political authority, diplomatic strength and military power. Among them, the key importance is attributed to the population which is an essential power-building factor. The idea of such a thesis is reflected in the position of many scientists who have so far presented their own concepts of determining the power of the state. They are manifested in the form of proprietary models of the power of the state or in the form of a closed catalogue of enumerated specified power components.

The human factor as a component of the power of the state was expressed in the concepts of, among others, scholars such as Mirosław Sułek, Arvind Virmani (although the location of the population size in the denominator of the formula developed by the author ultimately diminishes the power of the populous countries), Ray S. Clin, Frank Clifford German, Halford Mackinder, Hans Joahim Morgenthau, John Stoessinger, Nicholas Spykman, Raymond Aron, Wilhelm Fucks, Vladimir Rubenovich Chaczaturov, Jean-Yves Caro, Allen Mayhew Shinn, Abramo Fimo Organski, Paul Kennedy, Kenneth Waltz, John Maersheimer, Daniel Papp, J. David Singer, Norman Z. Alcock and Alan G. Newcomb, Rudolf Steinmetz, Guido Fisher, Margaret Ball and Hugh Killough, Alfred de Grazia and Tom H. Stevenson, Federic Hartmann, Leszek Moczulski, Dariusz Kondrakiewicz, Marcin Kleinowski and Ashley J. Tellis, Janice Bially, Christopher Layne, Melissa McPherson (RAND Corporation). The above - mentioned researchers included the demographic factor in the form of the following indicators: population size, number of soldiers, number of people in the working age, population density, population dynamics, population structure, urban population, intellectual potential, ratio between population in conscription age and size of the armed forces, number of soldiers in active service, organisational and decision-making capabilities, and others.

15 J.G. Stoessinger, The Might of Nations: World Politics in Our Time, New York 1969, p. 27.

16 R. Dahl, "The concept of power", Behavioral Science 1957, no. 2, p. 203.

17 R. Aron, Pokój i wojna między narodami (teoria), transl. A. Mielczarek, Warszawa 1995, p. 69 . 
It is also worth highlighting Zbigniew Lach's review of the frequency of selection of specific factors to models of the power of the state. It allows us to observe the researchers' partial preferences in this area (Fig. 1). However, by reviewing some of the models existing in the literature (28 theoretical models for measuring power), this classification should be regarded as indicative. The following systematisation demonstrates that the population is the most frequently used component in models of the power of the state taken into consideration.

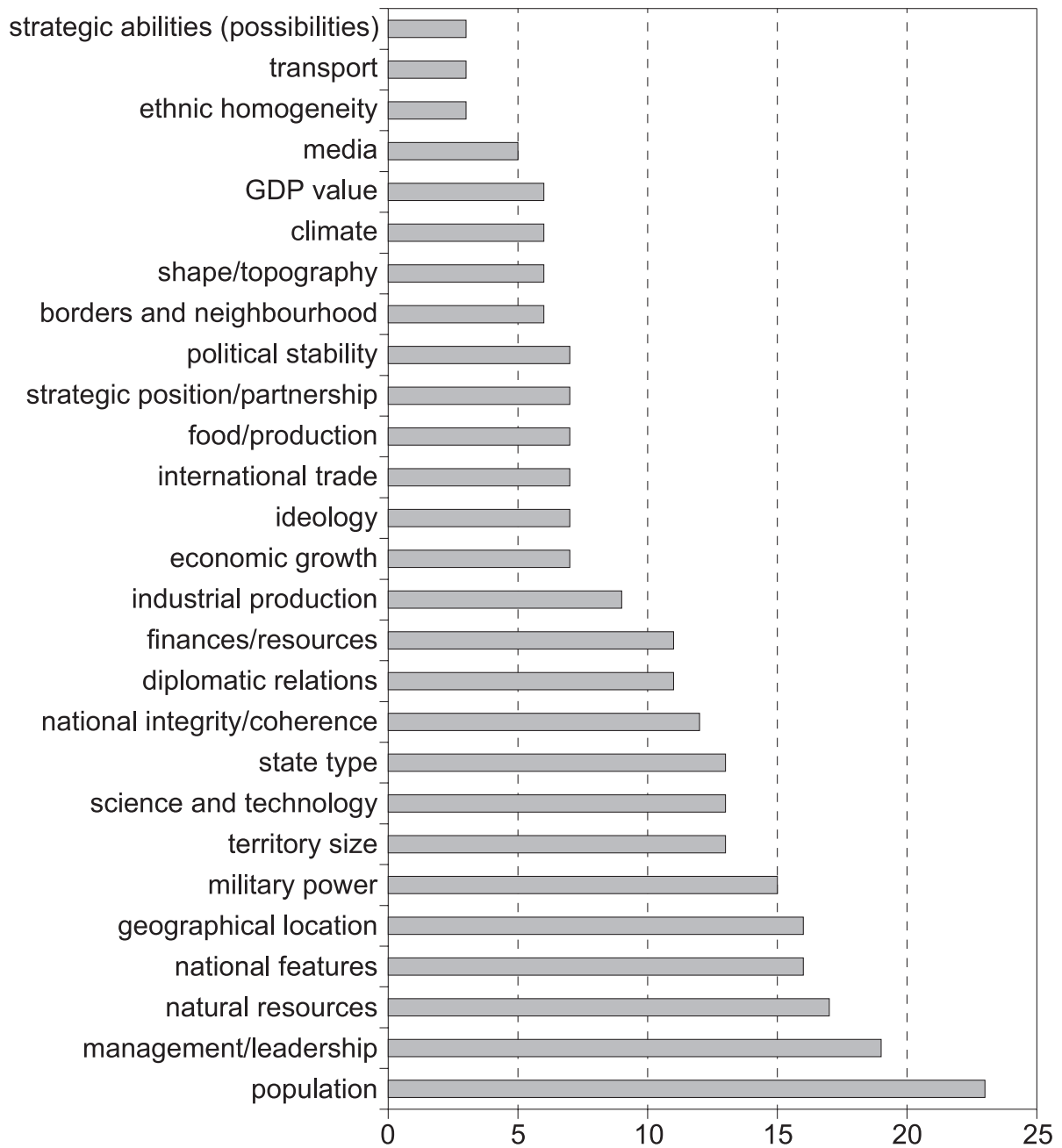

Figure 1. Repeatability of selection of individual indicators in models of the power of the state

Source: own study based on Z. Lach, "Analiza poziomu rozwoju społeczno-ekonomicznego i potęgi państw Europy Środkowo-Wschodniej”, Przeglad Geopolityczny 9, 2014, p. 40. 


\section{Selection of factors to be included in the model of assessing the demographic power of the state}

Analysis of the source literature made it possible to depict the demographic area by means of 24 factors which, in the author's opinion, provide the best characteristics of this area of the state's functioning. As part of the research, only "hard" factors were adopted, that is having measurable form, enabling quantification. Their enumeration is shown in Table 1. The statistical analysis presented below covers the demographic sphere of six European countries - Poland, Czech Republic, Slovakia, Hungary, Germany and Romania.

In order to identify and implement a set of independent variables for the model of assessing the demographic power of the state, a statistical analysis of the matrix of Pearson's linear correlation coefficients was performed for all factors listed in Table 1.

Based on the preliminary statistical analysis of demographic factors (Table 1), a set of explanatory variables characterised by low values of mutual correlation coefficients was obtained. Table 2 presents the values of Pearson's linear correlation coefficients for 12 out of 24 explanatory variables selected for further analysis.

Table 1. Demographic indicators taken into account in the analysis

\begin{tabular}{|l|l|}
\hline $\mathrm{x}_{1}$ & Population \\
\hline $\mathrm{x}_{2}$ & Country population as $\%$ of total EU population \\
\hline $\mathrm{x}_{3}$ & Population growth rate $(\%)$ \\
\hline $\mathrm{x}_{4}$ & Population density (per $\left.1 \mathrm{~km}^{2}\right)$ \\
\hline $\mathrm{x}_{5}$ & Fertility rate - number of children per 1 woman \\
\hline $\mathrm{x}_{6}$ & Birth rate per 1,000 population \\
\hline $\mathrm{x}_{7}$ & Mortality rate per 1,000 population \\
\hline $\mathrm{x}_{8}$ & Number of migrants per 1,000 population \\
\hline $\mathrm{x}_{9}$ & Migration balance per 1,000 population \\
\hline $\mathrm{x}_{10}$ & Average life expectancy \\
\hline $\mathrm{x}_{11}$ & Live birth rate per 1,000 population \\
\hline $\mathrm{x}_{12}$ & Infant mortality per 1,000 births \\
\hline $\mathrm{x}_{13}$ & Higher education - between 25 and 64 years of age \\
\hline $\mathrm{x}_{14}$ & Population aged 65 and more as $\%$ of total population \\
\hline $\mathrm{x}_{15}$ & Age dependency ratio \\
\hline
\end{tabular}


Alicja Paluch

\begin{tabular}{|l|l|}
\hline $\mathrm{x}_{16}$ & Average age \\
\hline $\mathrm{x}_{17}$ & Population in working age as \% of total population \\
\hline $\mathrm{x}_{18}$ & Marriage rate per 1,000 population \\
\hline $\mathrm{x}_{19}$ & Divorce rate per 1,000 population \\
\hline $\mathrm{x}_{20}$ & Adult literacy $(\%)$ \\
\hline $\mathrm{x}_{21}$ & Emigration level \\
\hline $\mathrm{x}_{22}$ & Immigration level \\
\hline $\mathrm{x}_{23}$ & Urban population as \% of total population \\
\hline $\mathrm{x}_{24}$ & Rural population as \% of total population \\
\hline
\end{tabular}

Source: own study based on: Eurostat, CIA, Worldometers, The World Bank, World Atlas. Data for the years: 2016-2018.

Table 2. Mutual correlation coefficients of explanatory variables selected as part of the preliminary analysis

\begin{tabular}{|l|c|c|c|c|c|c|c|c|c|c|c|c|}
\hline & $\mathbf{X}_{\mathbf{1}}$ & $\mathbf{X}_{\mathbf{2}}$ & $\mathbf{X}_{\mathbf{3}}$ & $\mathbf{X}_{\mathbf{5}}$ & $\mathbf{X}_{\mathbf{7}}$ & $\mathbf{X}_{\mathbf{8}}$ & $\mathbf{X}_{\mathbf{1 3}}$ & $\mathbf{X}_{\mathbf{1 4}}$ & $\mathbf{X}_{\mathbf{1 9}}$ & $\mathbf{X}_{\mathbf{2 0}}$ & $\mathbf{X}_{\mathbf{2 1}}$ & $\mathbf{X}_{\mathbf{2 3}}$ \\
\hline $\mathbf{X}_{\mathbf{1}}$ & 1 & & & & & & & & & & & \\
\hline $\mathbf{X}_{\mathbf{2}}$ & 1.00 & 1 & & & & & & & & & & \\
\hline $\mathbf{X}_{\mathbf{3}}$ & -0.20 & -0.20 & 1 & & & & & & & & & \\
\hline $\mathbf{X}_{\mathbf{5}}$ & 0.09 & 0.09 & 0.40 & 1 & & & & & & & & \\
\hline $\mathbf{X}_{\mathbf{7}}$ & -0.08 & -0.08 & -0.84 & -0.06 & 1 & & & & & & & \\
\hline $\mathbf{X}_{\mathbf{8}}$ & 0.10 & 0.10 & 0.46 & 0.90 & -0.03 & 1 & & & & & & \\
\hline $\mathbf{X}_{\mathbf{1 3}}$ & 0.60 & 0.60 & 0.28 & 0.20 & -0.48 & 0.13 & 1 & & & & & \\
\hline $\mathbf{X}_{\mathbf{1 4}}$ & 0.67 & 0.67 & -0.19 & 0.54 & 0.36 & 0.66 & 0.22 & 1 & & & & \\
\hline $\mathbf{X}_{\mathbf{1 9}}$ & 0.02 & 0.02 & 0.64 & 0.82 & -0.22 & 0.95 & 0.29 & 0.50 & 1 & & & \\
\hline $\mathbf{X}_{\mathbf{2 0}}$ & -0.03 & -0.03 & 0.41 & -0.22 & -0.71 & -0.39 & 0.64 & -0.61 & -0.15 & 1 & & \\
\hline $\mathbf{X}_{\mathbf{2 1}}$ & 0.98 & 0.98 & -0.34 & -0.04 & 0.05 & -0.01 & 0.45 & 0.66 & -0.11 & -0.15 & 1 & \\
\hline $\mathbf{X}_{\mathbf{2 3}}$ & 0.45 & 0.45 & 0.17 & 0.77 & 0.11 & 0.86 & 0.47 & 0.84 & 0.82 & -0.29 & 0.34 & 1 \\
\hline
\end{tabular}

Source: own study.

Table 3. Selected groups of demographic factors

\begin{tabular}{|c|c|c|c|}
\hline GROUP 1 & Population & Mortality rate & Migration rate \\
\hline Population & 1 & -0.08 & 0.10 \\
\hline Mortality rate & -0.08 & 1 & -0.03 \\
\hline Migration rate & 0.10 & -0.03 & 1 \\
\hline
\end{tabular}




\begin{tabular}{|c|c|c|c|}
\hline GROUP 2 & $\begin{array}{c}\text { Country } \\
\text { population as } \\
\% \text { of total EU } \\
\text { population }\end{array}$ & Adult literacy & Fertility rate \\
\hline $\begin{array}{l}\text { Country population as } \% \text { of total EU } \\
\text { population }\end{array}$ & 1 & -0.03 & 0.09 \\
\hline Adult literacy & -0.03 & 1 & -0.22 \\
\hline Fertility rate & 0.09 & -0.22 & 1 \\
\hline GROUP 3 & $\begin{array}{c}\text { Country } \\
\text { population as } \\
\% \text { of total EU } \\
\text { population }\end{array}$ & $\begin{array}{l}\text { Population } \\
\text { growth rate }\end{array}$ & Fertility rate \\
\hline $\begin{array}{l}\text { Country population as } \% \text { of total EU } \\
\text { population }\end{array}$ & 1 & -0.2 & 0.09 \\
\hline Population growth rate & -0.2 & 1 & 0.4 \\
\hline Fertility rate & 0.09 & 0.4 & 1 \\
\hline GROUP 4 & Higher education & $\begin{array}{l}\text { Population } \\
\text { growth rate }\end{array}$ & $\begin{array}{l}\text { Population } \\
\text { aged } 65 \text { and } \\
\text { more as \% of } \\
\text { total population }\end{array}$ \\
\hline Higher education & 1 & 0.28 & 0.22 \\
\hline Population growth rate & 0.28 & 1 & -0.19 \\
\hline Population ageing & 0.22 & -0.19 & 1 \\
\hline GROUP 5 & Emigration level & $\begin{array}{l}\text { Population } \\
\text { growth rate }\end{array}$ & $\begin{array}{c}\text { Urban } \\
\text { population }\end{array}$ \\
\hline Emigration & 1 & -0.34 & 0.34 \\
\hline Population growth rate & -0.34 & 1 & 0.17 \\
\hline Urban population & 0.34 & 0.17 & 1 \\
\hline GROUP 6 & Emigration level & Adult literacy & Divorce rate \\
\hline Emigration & 1 & -0.15 & -0.11 \\
\hline Adult literacy & -0.15 & 1 & -0.15 \\
\hline Divorce rate & -0.11 & -0.15 & 1 \\
\hline
\end{tabular}

Source: own study.

As a result of the analysis, six groups of demographic factors were identified, demonstrating low values of Pearson's mutual linear correlation coefficients. Among the above solutions, the smallest absolute values of Pearson's mutual linear correlation coefficients were noted in Group 1, which includes the follow- 
ing factors: population, mortality rate and migration rate. It should be noted, however, that Group 2 and Group 6, which include a dult literacy taking a similar level in the countries indicated may distort the final result of the estimated power of those countries. Therefore, these solutions should be considered the least reflecting the real level of power. Analysing the individual groups (Table 3) it seems appropriate to develop a model of demographic power of the state, taking into account factors included in Group 1, that is, population, mortality rate and migration rate.

\section{Conclusions}

The existing correlation between the population potential and the power of the state cannot be denied. Nor can one disagree with the thesis that "the ability of states to maintain and develop their power remains in direct dependence on the demographic factor". ${ }^{18}$ It should be noted, however, that the power of the state cannot be identified solely with its absolute population. As P. Buhler pointed out, "a large population is neither a sufficient nor a necessary condition for power, even though both have often coexisted" ${ }^{19}$ Possibilities and potential of the strength focused in human capital should be studied primarily in terms of the demographic structure and psychological features of population. This is the reason for the analysis of demographic power-building factors in the article, which in the further part of the author's research will be applied in the process of building an analytical sub-model for assessing the power of the state in the demographic area.

Despite the polarisation of positions in relation to the significance of the demographic factor in shaping the general power of the state visible in the source literature, the position of P. Buhler should be assumed who stated that "dynamics [of demography] gives form to the material which is the muscle of power". ${ }^{20} \mathrm{As}$ a result, omitting this power-building area in research would significantly diminish the real potential of the political entity.

\section{Bibliography}

Aron R., Pokój i wojna między narodami (teoria), transl. A. Mielczarek, Warszawa 1995.

Białek J., Oleksiuk A., Gospodarka i geopolityka. Dokad zmierza świat?, Warszawa 2009.

Buhler P., O potędze w XXI wieku, transl. G. Majcher, Warszawa 2014.

Dahl R., "The concept of power", Behavioral Science 1957, no. 2.

Florczak W., Przybyliński M., "Zmiany w liczebności i strukturze populacji a rozwój społeczno-ekonomiczny”, Studia Ekonomiczne 2016, no. 3.

18 M. Lakomy, op. cit., p. 129.

19 P. Buhler, op. cit., pp. 20-21.

20 Ibid., p. 225. 
Kondrakiewicz D., "Państwo", [in:] Międzynarodowe stosunki polityczne, ed. M. Pietraś, Lublin 2006. Lach Z., "Analiza poziomu rozwoju społeczno-ekonomicznego i potęgi państw Europy Środkowo-Wschodniej”, Przeglad Geopolityczny 9, 2014.

Le Bras H., L'adieu aux masses. Demographie et politique, Paris 2002.

Łakomy M., "Bezpieczeństwo demograficzne a potęga państw", Przegląd Geopolityczny 19, 2017.

Łoś-Nowak T., ed., Stosunki międzynarodowe, Kraków 2002.

Mackinder H.J., "The geographical pivot of history”, The Geographical Journal 23, 1904, no. 4.

Mearsheimer J., The Tragedy of Great Power Politics, New York 2001.

Morgenthau H.J., Polityka między narodami: walka o potęgę i pokój, ed. K.W. Thompson, transl. R. Włoch, Warszawa 2010.

Stoessinger J.G., The Might of Nations: World Politics in Our Time, New York 1969.

Zając K., "Z historii badań związków rozwoju społeczno-ekonomicznego a demograficznego", http:// stat.gov.pl/cps/rde/xbcr/gus/POZ_Z_historii_badan_zwiazkow_rozwoju_spol-ekonom_a_demogr.pdf (accessed: 25.08.2018).

Załęski K., Międzynarodowe stosunki polityczne. Wybrane problemy, Dęblin 2011.

\title{
DEMOGRAPHIC DETERMINANTS OF THE POWER OF THE STATE
}

\section{Summary}

Connections between demographic conditions of the state and its power have become a reason for the author's attempt to identify key power-building factors featuring demographic nature. For this purpose, a statistical analysis based on data from selected European countries such as Poland, Czech Republic, Slovakia, Hungary, Germany and Romania was carried out. The outcome of the research allowed the author to obtain six groups of explanatory variables for the model of assessing the power of the state in the demographic area.

Keywords: power of the state, power-building factors, demographic factors.

\author{
Alicja Paluch \\ ala.paluch1@wp.pl
}

Studia nad Autorytaryzmem i Totalitaryzmem 41, nr 1, 2019

(C) for this edition by CNS 